\title{
A Proposal to Evaluate the Potential of Biogas and Lifetime of Landfills for the Production of Electrical Energy
}

\author{
Mariana Nalesso Gonçalves ${ }^{1}$, Matheus Ribeiro Martins ${ }^{2}$ and José Roberto Camacho ${ }^{1}$ \\ ${ }^{1}$ Department of Electrical Engineering \\ Universidade Federal de Uberlândia \\ Campus of Uberlândia - Uberlândia (Brazil) \\ Phone/Fax number:+55 34 99100-0972, e-mail: nalessomariana@gmail.com \\ ${ }^{2}$ Department of Electrical Engineering \\ Universidade Federal de Uberlândia \\ Campus of Uberlândia - Uberlândia (Brazil) \\ e-mail: matheusr.martins@hotmail.com \\ ${ }^{3}$ Department of Electrical Engineering \\ Universidade Federal de Uberlândia \\ Campus of Uberlândia - Uberlândia (Brazil) \\ e-mail: jrcamacho@ufu.br
}

\begin{abstract}
.
A study is presented to evaluate the biogas potential of landfills for the production of electric energy. Based on the mathematical method suggested by the Intergovernmental Panel on Climate Change (IPCC) for calculating methane emissions, a program developed in the GNU Octave software that measures these emissions and the energy potential presented by the landfill under study. This is a very important issue on energy production from human waste, and under the topic of Earth environment conservation and cleaning.

Through the software developed, a case study was carried out at the Uberlândia-MG-Brasil landfill, presenting the potential for biogas generation and electric energy, as well as the estimation of its useful life. Thus, a comparison was made of the results presented by the program and the actual data of the plant already in operation in the aforementioned landfill. This study showed that the methodology implemented in the software to quantify the potential of biogas and energy in landfills is valid, presenting approximation between real and estimated data during simulation. These are important aspects because they allow the investor in renewable energy, whether it is from the private sector or from the public sector, to have the true dimension of the financial gains and the enormous advantages for the environment.
\end{abstract}

\section{Key words}

Biogas, Landfill, Renewable Energy.

\section{Introduction}

According to ABRELPE - Brazilian Association of Public Cleaning and Special Waste Companies, in 2012 it was verified that more than 3 thousand Brazilian cities sent almost 24 million tons of waste to destinations deemed improper. In that same year, only $57 \%$ of the waste collected in the country was destined for landfills. Thus, we have 22 million tons of garbage annually sent to controlled landfills or dumps where they are not treated properly.

On average, for each ton of solid waste deposited in the landfill, $200 \mathrm{Nm}^{3}$ of biogas is generated (Johannessen, 1999). The viability for biogas energy exploration in landfills occurs where they receive at least 200 tons of waste daily and have a capacity over their useful life of 500 thousand tons.

The Brazilian Solid Waste Survey, published by ABRELPE in the year 2013, revealed that 3,334 municipalities made use of unsuitable sites for final waste disposal. Of this total, 1,569 municipalities used dumps, which is the worst form of disposal, with the disposal of all municipal waste directly on the ground, without any care or treatment. 
Within this context, this work aims to present the potential for biogas production from the decomposition of municipal solid waste, as well as its potential for the generation of electric energy. The methodology for calculating this potential as well as its implementation in GNU Octave software is presented in detail. Complementary results are the estimation of the useful life and the investment needed to obtain the proper performance of the landfill.

\section{Methodology}

\section{A. Calculation Methodology}

Initially the Degradable Organic Carbon (DOC) fraction is calculated, which is the composition of the waste and is based on the amount of carbon in each component of the waste mass. Table 1 shows the carbon contents for each component of the waste.

For the calculation of the potential for generation in landfills, we used the methodologies suggested in the Guide to National Greenhouse Gas Inventories of the IPCC, contained in the Workbook of 1996, Volume 2, Module 6: Waste; And the 2006 Guide, Volume 5, Chapters 2 - Waste Generation, Composition and Management Data; And 3 Disposal of Solid Waste.

Table 1 - Percentage of DOC (by mass) by type of waste.

\begin{tabular}{|l|l|}
\hline Component & $\begin{array}{c}\text { Percentage } \\
\text { (in mass) }\end{array}$ \\
\hline A) Paper and paperboard & 40 \\
\hline B) Garden and Park Waste & 17 \\
\hline C) Food Remains & 15 \\
\hline D) Textiles & 40 \\
\hline E) Wood and straw & 30 \\
\hline
\end{tabular}
SOURCE: BIRGEMER; CRUTZEN (1987)

$$
D O C=0,4 A+0,17 B+0,15 C+0,4 D+0,3 E
$$

The dissociated DOC fraction (DOCF) indicates how much of this carbon is accessible for biochemical decomposition.

$$
D O C_{F}=0,014 T+0,28
$$

Where $\mathrm{T}$ is the temperature in the anaerobic zone of the waste.

In deep sanitary landfills, even in harsh winters, there is no change in biogas production throughout the year (ROVERS 1997). The temperature in the anaerobic zone is regulated at the optimum point of the mesophilic temperature range. For this reas on, $\mathrm{T}$ is equal to $35^{\circ} \mathrm{C}$, which implies that the DOCF value is equal to 0.77 .

The methane generation potential at the residue ( $\mathrm{L} 0)$ in $\mathrm{kg}$ of methane per $\mathrm{kg}$ of residue is then calculated.

$$
L_{0}=M C F * D O C * D O C_{F} * F *\left(\frac{16}{12}\right)
$$

Where $\mathrm{MCF}$ is the methane correction factor in percentage, $\mathrm{F}$ is the volume fraction of methane in biogas, and $(16 / 12)$ is the conversion factor of carbon in methane.

The methane correction factor (MCF) varies depending on the type of site. The IPCC defines four types of sites: Inadequate Landfills, Controlled Landfills, Sanitary Landfills, and Unclassified Landfills, that can be seen in Table 2.

Table 2 - Methane Correction Factor in function of the Disposal Location.

\begin{tabular}{|c|c|}
\hline Layout Location Type & MCF \\
\hline Dumping ground & 0,4 \\
\hline Controlled landfill & 0,8 \\
\hline Sanitary landfill & 1 \\
\hline Uncategorized sites & 0,6 \\
\hline SouRCE: IPCC (1996)
\end{tabular}

To convert $\mathrm{L} 0$ to $\mathrm{m} 3$ biogas/TONresidue, we divide $\mathrm{L} 0$ by 0.0007168 ton $/ \mathrm{m} 3$ (methane density). We then calculate the amount of methane emitted per year $(\mathrm{Q})$ in the landfill (m3 CH4/year).

$$
Q=k * R_{x} * L_{0} * e^{-k(x-T)}
$$

Where $\mathrm{k}$ is the decay constant, $\mathrm{Rx}$ is the waste stream in the year in tonnes, $\mathrm{L} 0$ the methane generation potential in $\mathrm{m} 3$ biogas/TONresidue, $\mathrm{x}$ the current year and $\mathrm{T}$ the year of deposition of the residue in the landfill.

According to Table 3, that can be found in IPCC's Guide of 2006, Volume 5 - Residues, Chapter 3 - Disposal of Solid Residues, for the tropical climate, ie wet wastes, we have:

Table 3 - Methane Generation Constant for Wet Waste.

\begin{tabular}{|c|c|}
\hline Residue & $\mathrm{K}$ \\
\hline Paper & 0,07 \\
\hline Organic Waste & 0,17 \\
\hline Textiles & 0,07 \\
\hline Wood & 0,035 \\
\hline \multicolumn{2}{|c|}{ SoURCE: IPCC (2006) }
\end{tabular}

For the calculation of power and energy, we use the equations:

$$
P=\frac{Q * L C P * \eta}{860000}
$$

Where $\mathrm{P}$ is the Available Power (MW), Q is the methane flow rate captured by the drainage system, LCP is the 
Lower Calorific Power of Methane, $\eta$ is the efficiency of the motors, 860000 is the conversion factor from kcal to MW.

$$
E=P * \eta * \text { Time }
$$

Where $\mathrm{E}$ is the available Energy (MWh/ day), $\eta$ is the efficiency of the motors operating at full load and Time is the operating time of the motors.

Thus, as a function of the methane flow collected by the landfill system, the calculations of the power (MW) and energy (MWh / day) available during the lifetime of the landfill can be performed.

\section{B. Software}

\section{1) Considerations}

Knowing that food and organic wastes are deposited together, and that the amount of tissue deposited is very small, we calculate DOC as:

$$
D O C=0,4 A+0,16(B+C)+0,3 E
$$

For the calculation of the available energy (MWh/day), an operation time of $24 \mathrm{~h} /$ day was considered for the engines.

\section{2) Software Operation}

Before running the program, a table should be filled, with the quantities of tons of waste deposited since the beginning of the operation of the landfill, and estimates of the deposits over its useful life.

With the waste disposal table completed, the program is executed and the user is required to enter technical data regarding the operation of the landfill.

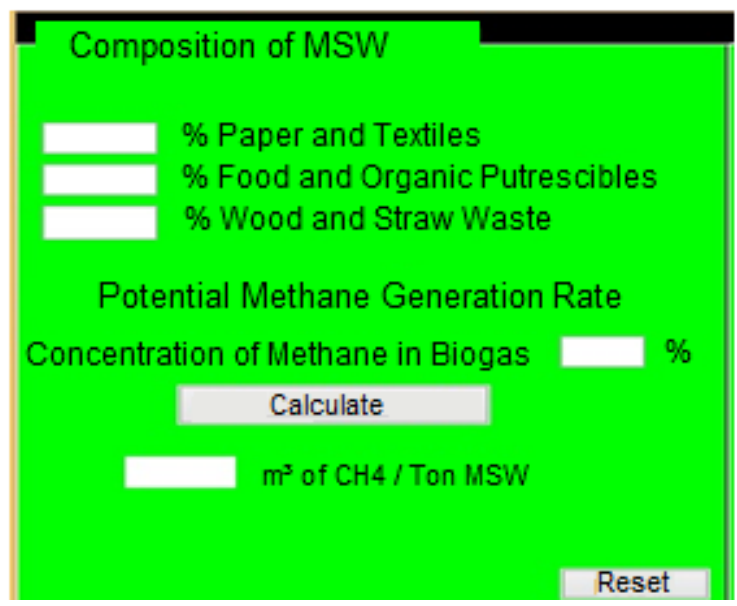

Figure 1 - Interface Capture: MSW Features

In the MSW Composition interface, as show in figure 1, the user will enter the percentage data referring to the characteristics of the residues deposited in the landfill as well as the concentration of methane present in the biogas, and the software will present the potential that each ton of that residue has for the generation of methane.

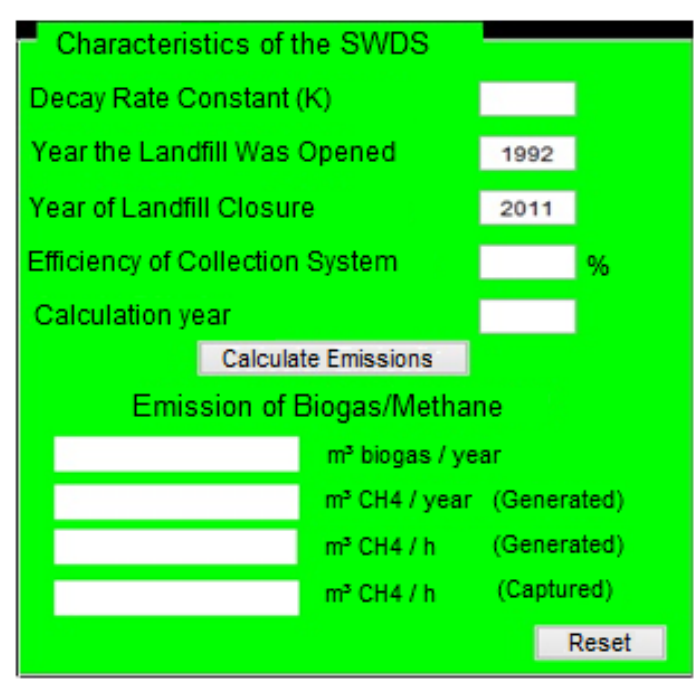

Figure 2 - Interface Screen Capture: Characteristics of the SWDS.

In the Characteristics of the SWDS interface, as show in figure 2, the user will enter the landfill data, the biogas capture system, and the desired year of calculation, and the software will present the methane and biogas emissions for the requested year.

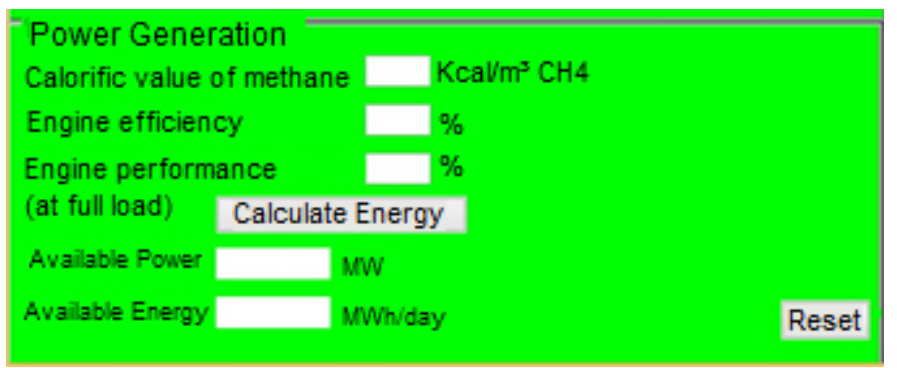

Figure 3 - Interface Capture: Power Generation.

In the Power Generation interface, as show in figure 3, the user will enter the methane data, as well as the data of the energetic plant implanted or designed for the landfill, and so the software will provide the Power and Energy data available for that particular year.

In Figure 4 - Interface Caption: Lifetime Projections, the software presents a projection of the biogas (m3/year) and methane (m3/year) emissions, as well as the power (MW) and energy (MWh/day) available in up to 20 years period after the closure of the landfill. 


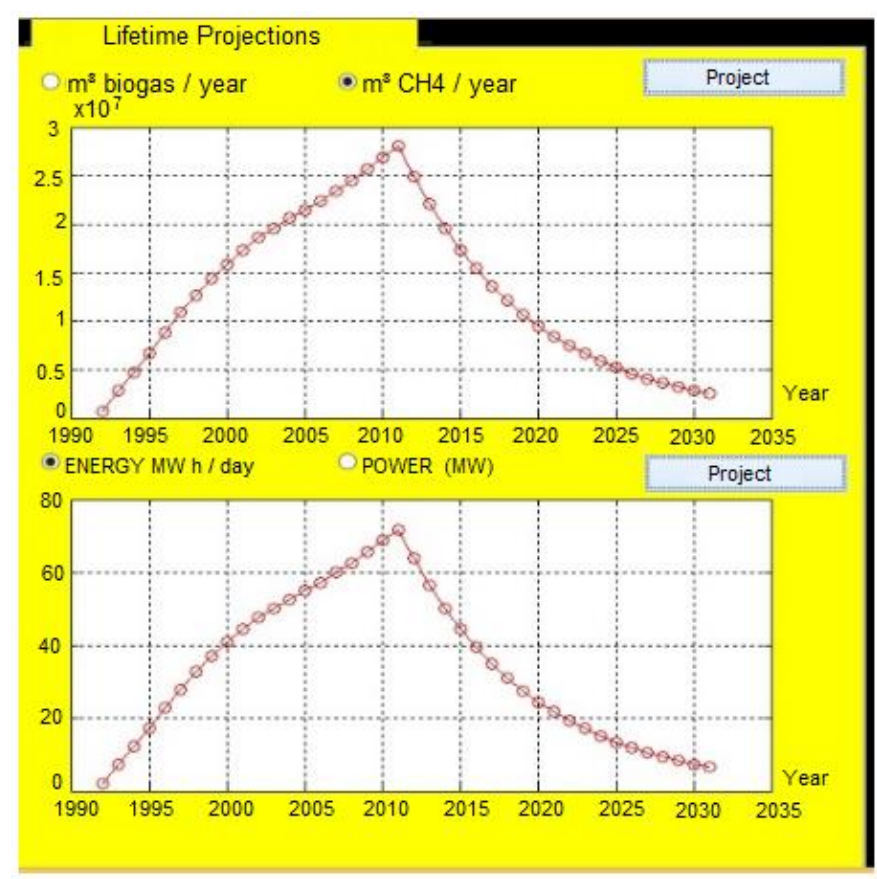

Figure 4 - Interface Capture: Lifetime Projections

\section{Discussion and Results}

The case study was carried out in the landfills of the city of Uberlândia - MG, located in the West Sector of the Municipality, near the roundabout of José Andraus Gassani Avenue with the Highway Ring - Sector West. Located between the following UTM geographic coordinates (Official Datum: Corrego Alegre): $\mathrm{E}=781,600.00$ and $782,600.00$ meters; $\mathrm{N}=7,910,100.00$ and 7,910,800.00 meters.

The landfill is divided in two parts, one of them, closed in 2010, and the second one, located next to the first, with opening in the same period. The first part, during its 16 years of operation, received about 2,100,000 tons of household and special waste.

Detailed calculations on the life of the landfill according to the ECP (Environmental Control Plan), indicated a volumetric landing capacity of 4,202,755.19 m3; Which is equivalent to 21 years of useful life starting in 2010 and ending in 2031.

Table 4 shows the evolution of the quantities of household and similar waste collected and disposed in the landfill since August 1995, and the amount of waste to be received by the year 2031, it should be noted that up to 2010 the waste was discarded in the old landfill.

\begin{tabular}{c|cccc}
\hline Year & $\begin{array}{c}\text { Business } \\
\text { waste } \\
\text { (ton) }\end{array}$ & $\begin{array}{c}\text { Household } \\
\text { waste } \\
\text { (ton) }\end{array}$ & $\begin{array}{c}\text { Amount } \\
\text { received } \\
\text { (ton) }\end{array}$ & $\begin{array}{c}\text { Estimated } \\
\text { Amount } \\
\text { (ton) }\end{array}$ \\
\hline 1995 & 0.00 & 34,664 & 34,664 & ------- \\
1996 & 41,965 & 109,992 & 151,958 & ------ \\
1997 & 25,427 & 97,961 & 119,350 & ------ \\
1998 & 13,630 & 105,720 & 119,350 & ------ \\
1999 & 14,783 & 114,873 & 129,656 & ------ \\
2000 & 20,402 & 120,256 & 140,657 & ------ \\
2001 & 18,745 & 121,110 & 139,855 & ------ \\
2002 & 18,753 & 120,405 & 139,157 & ------ \\
2003 & 14,654 & 111,005 & 125,659 & ------ \\
2004 & 11,878 & 112,343 & 124,222 & ------ \\
2005 & 13,622 & 112,273 & 125,895 & ------ \\
2006 & 18,186 & 121,093 & 139,279 & ------ \\
2007 & 20,174 & 123,135 & 143,308 & ------ \\
2008 & 18,131 & 130,695 & 148,825 & ------ \\
2009 & 20,580 & 141,005 & 161,585 & ------ \\
2010 & 16,318 & 149,744 & 166,063 & ------ \\
2011 & 18,863 & 156,692 & 175,556 & ------ \\
2012 & 23,3745 & 162,576 & 185,951 & ------ \\
2013 & 21,927 & 168,573 & 190,500 & ------ \\
2014 & 25,712 & 173,148 & 198,860 & ------ \\
2015 & 27,284 & 177,700 & 204,984 & ----- \\
2016 & 29,200 & 182,000 & ------- & 211,200 \\
2017 & 31,200 & 187,200 & ------ & 218,400 \\
2018 & 33,200 & 192,200 & ------- & 225,400 \\
2019 & 35,200 & 197,200 & ------ & 232,400 \\
2020 & 37,200 & 202,200 & ------ & 239,400 \\
2021 & 39,200 & 207,200 & ------- & 246,400 \\
2022 & 41,200 & 212,200 & ------ & 253,400 \\
2023 & 43,200 & 217,200 & ------ & 260,400 \\
2024 & 45,200 & 222,200 & ------ & 267,400 \\
2025 & 47,200 & 227,200 & ------ & 274,400 \\
2026 & 49,200 & 232,200 & ------- & 281,400 \\
2027 & 51,200 & 237,200 & ------- & 288,400 \\
2028 & 53,200 & 242,200 & ------ & 295,400 \\
2029 & 55,200 & 247,200 & ------ & 302,400 \\
2030 & 57,200 & 252,200 & ------ & 309,400 \\
2031 & 59,200 & 257,200 & ------ & 316.400 \\
\hline & & & & \\
\hline
\end{tabular}

Table 4 - Volume of waste deposited/estimated - Landfill of Uberlandia

The evaluations of the landfill documents, together with the visit made and the information provided by the engineers of the companies Limpebras and Energas, enabled the collection of the necessary information for the calculation, as shown in the table 5 . 
Table 5 - Landfill Characteristics Information Collected

\begin{tabular}{|c|c|c|}
\hline \multicolumn{2}{|c|}{ Information Collected } & Source \\
\hline $\begin{array}{l}\text { Gravimetric } \\
\text { composition of } \\
\text { waste }\end{array}$ & $\begin{array}{c}\text { Cardboard/Fabrics: } \\
10.53 \% \\
\text { Food/Organic waste: } \\
60.37 \% \\
\text { Wood waste: } 10.28 \% \\
\text { Glass: } 1.6 \% \\
\text { Plastic: } 15.87 \% \\
\text { Metal: } 1.35 \%\end{array}$ & Limpebras \\
\hline $\begin{array}{l}\text { Concentration of } \\
\text { methane in biogas }\end{array}$ & $55 \%$ & Energas \\
\hline $\begin{array}{c}\text { Start of landfill } \\
\text { operation }\end{array}$ & 1995 & SUPRAM \\
\hline $\begin{array}{l}\text { Prediction of } \\
\text { landfill closure }\end{array}$ & 2031 & SUPRAM \\
\hline Total landfill area & $300,000 \mathrm{~m}^{2}$ & SUPRAM \\
\hline Decay constant $(\mathrm{K})$ & 0.09 & IPCC \\
\hline $\begin{array}{c}\text { Efficiency of } \\
\text { collection system }\end{array}$ & $60 \%$ & Energas \\
\hline $\begin{array}{l}\text { Calorific Power of } \\
\text { methane estimate }\end{array}$ & $6050 \mathrm{Kcal} / \mathrm{m} 3 \mathrm{CH} 4$ & Energas \\
\hline $\begin{array}{l}\text { Efficiency of } \\
\text { motor-generator } \\
\text { sets }\end{array}$ & $40.4 \%$ & Energas \\
\hline $\begin{array}{l}\text { Performance of } \\
\text { motor-generator } \\
\text { sets }\end{array}$ & $85 \%$ & Energas \\
\hline
\end{tabular}

The biogas collection systems of the old and the new landfill are interconnected. Therefore, the calculation of the volume of waste deposited in the landfill has been considered since 1995 in the beginning of operation of the old landfill. The values of Table 5 related to the generation of energy (Performance, Efficiency and PCI of methane) were referenced to the power plant in operation at the Uberlândia landfill, which is managed by Energas.

Using the information in Tables 4 and 5 in the program developed throughout this work in the GNU Octave software, an estimation of the methane/biogas emissions and the potential of electric energy available over the life of the Uberlandia landfill.

Figure 5 shows the methane/biogas flow in the Uberlandia landfill from the beginning of operation in 1995 to the forecast for 20 years after landfill closure in 2051, which is when the production of biogas would become negligible according to the decay curve.

The amount of methane (CH4) generated in 2017 is 20,959,139 m3/year or 2,393 m3/hour as shown in Figure 6. The increasing behavior of the curve corresponds to the period in which the landfill receives garbage until the Year of 2031, because each ton of garbage adds a new potential. The maximum point of the curve corresponds to the last year of landfilling.

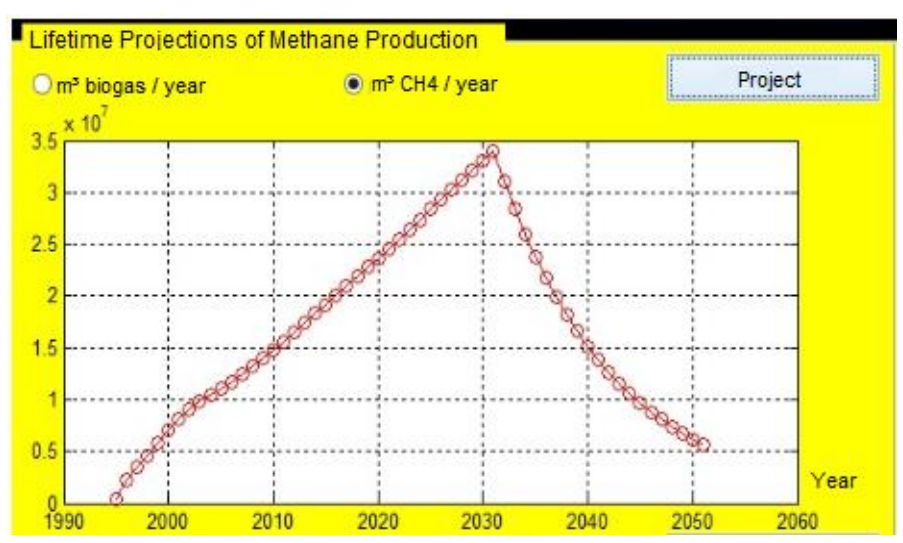

Figure 5 - Methane generation over the life of the landfill

The degradation of the organic matter in time, represented by the constant $\mathrm{K}(\mathrm{K}=0.09)$, characterizes the decay of the curve after the closure of the landfill characterizing its useful life for the production of gas.

As a function of the methane flow rate over time, the available power (MWh) and energy (MWh/day) calculations can be performed in the landfill. The available values for the year 2017 are: Power 4.08 MW and energy 83.23 MWh/day. The behavior of the energy and power availability curve can be observed in Figures 6 and 7, respectively.

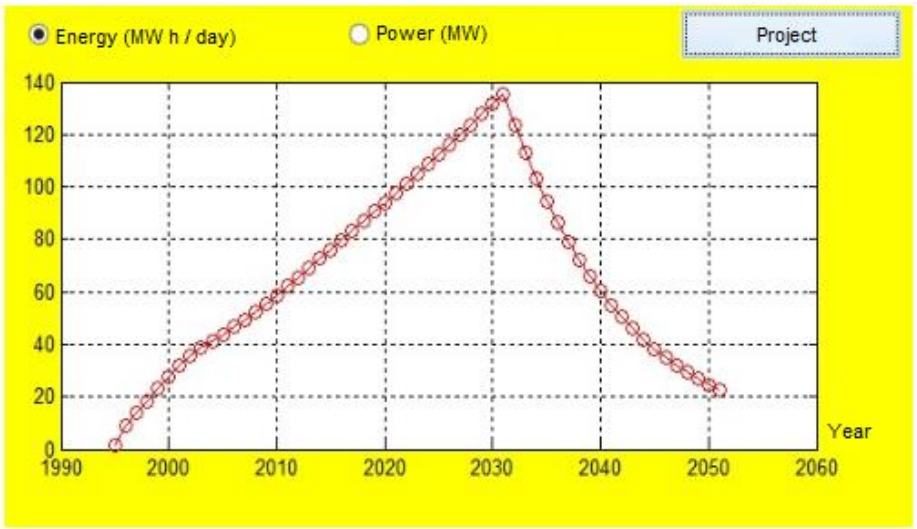

Figure 6 - Available energy in the landfill.

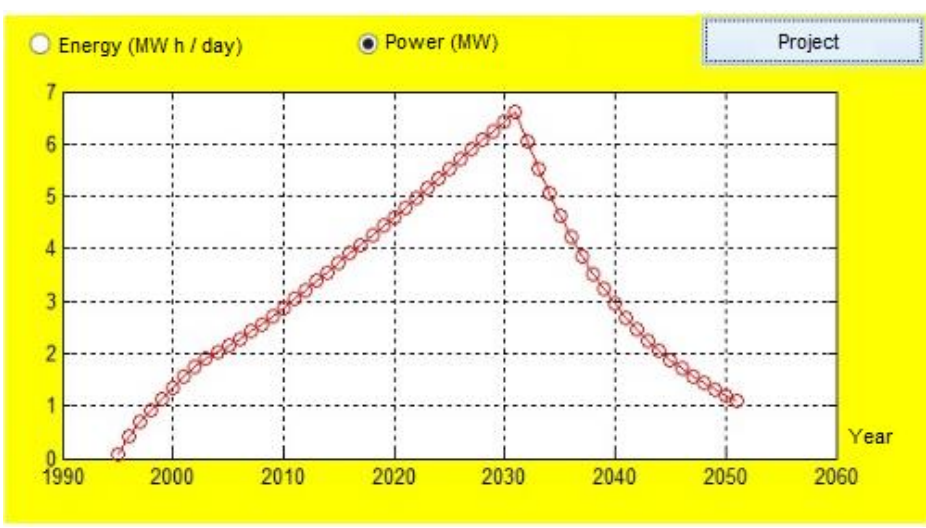

Figure 7 - Available power at the landfill. 
The simulation presents for the energy plant of the Uberlandia/MG landfill a power of $4.08 \mathrm{MW}$ for the year 2017. This value is in line with the current power of the Energas plant operating in the landfill, which presents in the same year a power of 2.8 MW through two GE J420 power generators with nominal power $1.425 \mathrm{MW}$.

We also have simulated data that the maximum power to be achieved by the landfill under study will be around $6 \mathrm{MW}$ in the last 4 years of operation. These figures also resemble those planned by the Energas company for the landfill. The plant's operating company plans to deploy a total of four $1.425 \mathrm{MW}$ power generators.

The analys is of the power and energy availability curve over the life of the landfill allows the knowledge of the feasibility of implementing projects to generate energy through biogas in landfills. In the case of implementation of such projects, these curves also provide a view of the periods throughout the useful life of the landfill in which it becomes feasible to expand the energy plant.

\section{Conclusions}

This work presents a computer program that calculates the viability of the biogas energy utilization in landfills.

In the current Brazilian scenario, we perceive a great difficulty of the public administration to make a correct management of solid urban waste, due to the great increase of the production of urban waste closely related to the development of the country. Projects like this make it possible to increase the use of clean energy sources in Brazilian cities.

This study also enables the optimized determination of the size of the landfill to observe the need to implement a new landfill in relation to the disposal of urban waste and energy production. The useful life of the landfill, closely related to the expected energy production, is another important point of observation in this research.

The use of the GNU Octave software developed during the work showed a satisfactory result, showing coherence between the simulated data and the actual data at the Uberlândia/MG landfill operation plant.

\section{References}

[1] ABRELPE. Associação Brasileira de Empresas de Limpeza Pública e Resíduos Especiais. Panorama dos resíduos sólidos no Brasil 2013. 31 p. São Paulo, Abril de 2014. Disponível em <http://www.abrelpe.org.br/Panorama/panorama2013.pdf>
_ (2010) Panorama dos resíduos sólidos no Brasil 2009. 210 p. São Paulo, Maio de 2010. Disponível em <http://www.abrelpe.org.br/Panorama/panorama2009.pdf>

(2012) Lançamento Panorama 2012. Disponível em $<$ http://www.abrelpe.org.br/noticias_detalhe.cfm?NoticiasID $=1$ 420>

[2] BEN. Balanço Energético Nacional 2014 (ano base 2013). Resultados Preliminares. Secretaria de Saneamento e Energia. Disponível em <https://ben.epe.gov.br/downloads〉.

[3] BIRGEMER, H.G. \& CRUTZEN, P.J. The production of methane from solid wastes. Journal of geophysical research, 1987. v. $92, \mathrm{n}^{\circ} \mathrm{D} 2$, pp 2181-2187.

[4] ENERGAS. Geração de Energia, 2015. Disponivel em < http://www.energasenergia.com.br-

/index.php?option $=$ com_phocagallery\&view $=$ categories \&Ite mid=143\&lang=pt-br>

[5] FIGUEIREDO, N. J. V. Utilização de biogás de aterro sanitário para geração de energia elétrica - Estudo de caso. 2011. 147P. Dissertação de mestrado. Programa de PósGraduação em Energia. Universidade de São Paulo.

[6] IEA - Internacional Energy Agency. Key world energy statistics. 82 p. França, 2014.

[7] IPCC - Climate Change 2013: The Physical Science Basis: Technical Summary. Contribution of Working Group I (WGI) to the Fifth Assessment Report (AR5) of the Intergovernmental Panel on Climate Change (IPCC), 2013.

_(1996) - International Panel on Climate Change. Guidelines for National Greenhouse Inventories: Reference Manual (Vol.3), 1996.

_(1996) - Painel Intergovernamental Sobre Mudança do Clima. Módulo 6 - Lixo, do Guia para Inventários Nacionais de Gases de Efeito Estufa. Volume 2: Livro de Trabalho, 1996.

_(2006) - Painel Intergovernamental Sobre Mudança do Clima. Módulo 5 - Resíduos. Volume 2: Geração de Resíduos, Composição e Gestão de Dados e Volume 3: Disposição de Resíduos Sólidos, 2006.

[8] JOHANNESSEN, L. M. Guidance Note on Recuperation of Landfill Gas from Municipal Solid Waste Landfills. Working Paper Series, 34 p. World Bank. Washington, 1999.

[9] LIMPEBRAS. Engenharia Ambiental, 2010.

[10] ROVERS, F. A.; TREMBLAY, J. J.; MOOJI, H., Procedures for landfill gas monitoring and control, Proceedings of an international seminar, Rep. Eps 4-EC-774, Fish. and Environ. Can., Waste Manage. Br., Ottawa, Ontario, 1977

[10] PMU. Prefeitura Municipal de Uberlândia. Plano de Gestão Integrada de Resíduos Sólidos do Municipio de 
Uberlândia. Uberlândia, 2013. Disponivel em < http://www.uberlandia.mg.gov.br/uploads/cmsb_arquivos/ 7929.pdf>

[11] SUPRAM. Superintendência Regional de Meio Ambiente e Desenvolvimento Sustentável. PARECER ÚNICO SUPRAM TM/AP Nº 633.008/2010. Uberlândia, 2010.

[12] UBERLÂNDIA. Banco de Dados Integrados de Uberlândia SEPLAN 2011, Volume III. Secretaria Municipal de

Planejamento Urbano. Disponivel em
<http://www.uberlandia.mg.gov.br/u ploads/cm s_b_arquivos /1428.pdf> 